\title{
A Change Is Gonna Come: African American Literature, Jazz and the Intersections of Time, Race, and Justice
}

\section{Chris Robinson}
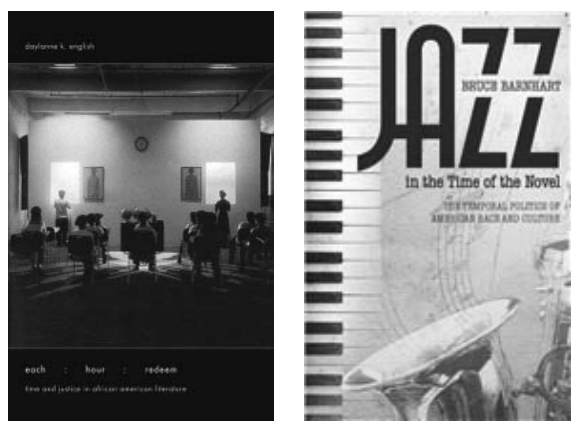

EACH HOUR REDEEM: Time and Justice in African American Literature. By Daylanne K. English. Minneapolis: University of Minnesota Press. 2013.

JAZZ IN THE TIME OF THE NOVEL: The Temporal Politics of American Race and Culture. By Bruce Barnhart. Tuscaloosa: The University of Alabama Press. 2013.

With a gruff and forceful delivery, the rapper Killer Mike raps on his song "Reagan" that "they declared the War on Drugs like a War on Terror. But what it really did was let the police terrorize whoever. But mostly black boys . . . But thanks to Reaganomics, prison turned the profits because free labor is the cornerstone of U.S. economics. Cause slavery was abolished unless you are in prison. You think I am bullshitting then read the thirteenth amendment. Involuntary servitude and slavery it prohibits. That's why they give drug offenders time in double digits." He notes related injustices suffered by the African American 
community on "Anywhere But Here." This time with a more relaxed, almost singing style that conveys a certain resignation about the ways African Americans are treated by the police, he laments that "even though it's black top from the mayors to the cops black blood still gets spilled. They raided her house no drugs were ever found but a black grandmother lay killed. Like the dream of the King when the sniper took his life on the balcony of Lorraine's Motel. ... . So you ask what happens to a dream deferred, Langston, well it kills itself." In both implicit and explicit ways, Killer Mike links his critiques to concepts of time. His answer to Langston Hughes' famous question speaks to the likelihood that the dream has not only been deferred, its presence and the possibility of realizing it in the future has been erased. His vivid portrayal of racial profiling, excessive prison sentencing, and the extreme use of police force points to the fact that African Americans live in a different time from whites, a time where justice and law enforcement is still executed as unfairly as it was long ago. The recent deaths of Michael Brown and Eric Garner at the hands of the police underscore the reality that Killer Mike is not just a pop musician exaggerating real life to sell records. Rather, his songs are both an indicator of the ways in which African Americans currently experience time and justice as well as a critique of the forces that structure that experience.

Fans and scholars of black music are well aware of the music's long history of social critique. Black music — whether it's by rappers like Killer Mike, NWA, or Public Enemy, contemporary jazz artists like saxophonist Howard Wiley, whose 2010 album 12 Gates to the City is about Angola State Penitentiary in Louisiana, spoken word artist Gil Scott-Heron, or classic jazz albums by Max Roach and Charles Mingus, and by musicians from much earlier - has always had an element of social, cultural, and political critique. Indeed, a large segment of black music, and black literature and arts in general, has concerned itself with time and justice. ${ }^{2}$ The two books reviewed here show that just like their musical counterparts, African American writers also address the complex relationship between time, justice, and race. More specifically, Daylanne K. English and Bruce Barnhart demonstrate the ways in which the concept of time can be used as either a disciplining and regulatory force, or as a tool to critique and challenge dominant constructions of time. They highlight the complex methods writers use to approach and critique the interweaving concepts of time, justice, and aesthetic form. ${ }^{3}$ English and Barnhart are concerned with historicizing, theorizing, and identifying the ways that the structuring of time can work to marginalize African Americans. They point to specific events, trends, and examples that African American writers have responded to in their writing, and they show how these writers use different literary genres, subject matter, and form to not only critique structures of time that marginalize them, but to provide new future possibilities as well.

In Each Hour Redeem Daylanne K. English addresses the entire African American literary tradition. Taking an interdisciplinary approach that draws from history, literary criticism, philosophy, and legal studies, English constructs a new analytic for understanding the whole of African American literature by 
focusing on the intersections of time, justice, race, and the way they influence and are represented through fiction. In teasing out these intersections she is able to draw connections between the "differential temporalities and differential justices" experienced by whites and blacks (3). She reminds readers that due to race and the inequities created by federal jurisprudence, African Americans have experienced time in drastically different ways than whites, and as such, African American literature reflects these differences in ways that complicate notions of a uniform conception of time. African American writers, English observes, are of their time and participate in their period's culture, clearly making them part of the American literary tradition. But paradoxically, through their different experience of time, they create and belong to a separate tradition. In this way, African American literature operates under a both/and logic. Or put differently, it is one manifestation of Du Bois' double consciousness. English argues that time, and the different ways in which African Americans have experienced it, "has always been a fundamental theme in African American literature, one that has worked to explore and expose the lived experience of race-bound justice in the United States" (22).

English shows how this separate temporal tradition stems from the ways in which slavery relegated African Americans outside modernity, which was governed by the organization of time. In a society where time and its management were the key to industry, commerce, and social and economic power, excluding blacks from time precluded their abilities to benefit from the opportunities and advantages it provided. African Americans' experience of time also had a strong relationship to state and federal law. This can be seen in the aftermath of Plessy v. Ferguson and the effects of Jim Crow laws, which effectively held African Americans back in time, denying their entry into modernity. English's approach to reading African American literature through the lenses of time and justice provides the means to trace the outlines of "racially differential justice in the United States" and to understand that "time and justice . . . are actually contingent and unevenly available: in other words, they are political fictions" $(23,24$, emphasis in original).

English's project of creating a new method to read African American literature is bold, and she takes great care to show the centrality of time and justice. English challenges Henry Louis Gates, Jr.'s "ur-trope" of the Talking Book, finding that Gates' focus on orality does not provide for adequate means to understand early black texts. ${ }^{4}$ She notes that in Olaudah Equiano's Interesting Narrative of the Life of Olaudah Equiano the narrator is first startled, not by a Talking Book, but by his master's watch, which leads English to conclude, contra Gates, that timekeeping is "positioned prior to discourse" (37, emphasis in original). She notes Sojourner Truth's purported lack of understanding of the concept of time, and uses Frederick Douglass' autobiographies to show how slaves did not know their birthdays, were unaware of their age, and were locked in a "perpetual laboring season" (28). Douglass' transition from slave to modern subject was also centered around time, which is seen in Matthew Brady's 1890 portrait of Douglass. English points out that Douglass' watch chain is clearly 
visible, and that his watch signified "the importance and business of a successful and representative American," and she argues that owning it allowed him to “occup[y] modern times" (45). Douglass' ability to manage his own time marks a stark departure from having been unable to experience modernity when his slave master dictated his schedule to him.

After making the case for the importance of time in the ways in which African Americans have experienced their world, English introduces two concepts that she calls "strategic anachronism" and "strategic presentism" to show the ways in which African American writers have dealt with time, race, and justice. Authors engaging in the former practice use older literary forms to critique the ongoing forms and practices of racial injustice and inequity. Authors who employ the latter practice take part in "active participation in and contribution to the philosophies, aesthetics, and politics of their period" (104). Although these two methods treat time and form in different ways, they are both concerned with critiquing the unequal state of African Americans in the United States.

Strategic anachronism can be found throughout the second half of the nineteenth century. During this time black literary production increased, which English attributes to a response to the continued disenfranchisement and social marginalization of African Americans. The appearance of novels coincides with the perception among African Americans that the federal government was actively working to suppress black citizenship. During this time, African American writers used novels, along with various forms of non-fiction such as newspapers, as tools to combat black disenfranchisement, legal inequality, and social marginalization. Novelists such as Frances Harper, Sutton Griggs, Pauline Hopkins, and Paul Laurence Dunbar challenged the pragmatism of Charles Sanders Peirce, William James, and Justice Oliver Wendell Holmes, as well as Supreme Court decisions from the 1880s and 1890s, such as Plessy v. Ferguson, the Slaughterhouse Cases, and cases concerning Chinese immigration. Pragmatism and Jim Crow segregation effectively pulled African Americans back into the antebellum period, and the literature that critiqued pragmatism and the federal government's jurisprudence, English argues, "represented racially specific experiences of both the law and time, experiences that invariably led to tragedy and injustice" (9). Pauline Hopkins was especially concerned with this phenomenon, and English analyzes Hopkins' turn-of-the-century novels Contending Forces and Winona to show how for Hopkins and her characters, the law is built to "force African Americans into an anachronistic state of noncitizenship" (73). English uses Holmes' phrase "temporal damage" to describe this enforcement of African Americans' noncitizenship through legal means, and it is this temporal damage anachronist writers have sought to address.

After a brief hiatus in the 1920 s, the middle of the twentieth century saw a resurgence of strategic anachronism. Black male lynching is an especially common trope in the literature of this period, and English points to Richard Wright's Native Son as a prime example. Like other anachronistic literature, such as Angelina Grimké's anti-lynching plays of the 1910s, Native Son and novels like it 
rely on older literary forms that are out of step with modern trends. And like his ancestors, English points out that Bigger Thomas inhabits a world excluded from linear time that is still dominated by Plessy v. Ferguson; it is closer to the 1890 s than the 1940s. Strategic anachronism was also a prominent practice in literature of the 1990s and 2000s. Like Wright, Ernest Gaines points to the continuing disproportionate incarceration and execution of black men through the common uses of naturalism and realism in his 1993 novel A Lesson Before Dying. The last few decades has also seen the flourishing of the hard-boiled detective fiction genre, which writers such as Walter Mosley and Barbara Neely — who English analyzes at length - turn to because it is well suited to conveying their critiques of racial injustice. This detective fiction, such as Mosley's 1994 novel Black Betty, is able to point out parallels between the time in which they are set and the present. In the case of Black Betty, Mosley is able to comment on racial politics, especially the relationship between the police and African Americans, in 1960s and 1990s Los Angeles. The detective genre allows Neely, whose novels feature detective Blanche White, to explore the realities of working class black women, the desire and inability to create a black community, and the past, present, and future of blackness. For Mosley, Neely, and other authors of contemporary detective fiction, they use the anachronistic process to imagine literary and political solutions to intra- and inter-racial problems. Furthermore, in setting their novels in the past to critique the present, Mosley, Neely, and their anachronist peers underscore that their characters are held back in time, occupying a different timeline from whites; or in English's formulation, they are "being black there" (143).

In contrast to Wright, Gaines, and Mosley, strategic presentist writers address racial inequality using a completely different approach and philosophy. As opposed to writers like Hopkins or Dunbar, writers of the Harlem Renaissance, the Dasein poets of the late 1950s, and the Black Nationalist and Black Arts Movement writers were less concerned with slavery and earlier racial grievances than they were with the dynamics of the present and actively being in their world. These writers, more so than their anachronist counterparts, English argues, "often chose literary forms inspired by the content and tempos of oral/ aural and folk black culture" (117). English highlights this with brief readings of Dasein poets Oswald Govan's and Walter De Legall's poems dedicated to Sonny Rollins and Miles Davis, and Amiri Baraka's reviews of jazz musicians Archie Shepp and Albert Ayler, all of which emphatically made connections with the present, were written in contemporary and experimental forms, and spoke to the now. ${ }^{5}$ In foregrounding this connection with music, English points to the interactions between writers' and musicians' uses and experiments with aesthetic forms - such as jazz saxophonist and trumpeter Joe McPhee's recording of Baraka's "It's Freedom Time."

After reading about the shifts between anachronism and presentism in African American literature for more than 150 years, readers are likely to wonder what factors drive this pendulum swing. English addresses this in the conclusion, where she underscores the "clear centrality of time in the African American 
literary tradition"- a claim she has convincingly and consistently argued (158). She contends that strategic presentism arises, along with its challenges to white supremacy, when African Americans focus on forging a large transnational diasporic community when national borders are experienced and/or perceived to be porous. This can be seen in the Harlem Renaissance's efforts at building a "transnational black "contemporaneity" (159) or in the Black Nationalist Movement's efforts to connect with global post-colonial struggles. This desire for diaspora and community, English notes, marked the 1920s and 1960s. This desire to build is in opposition to the methods of strategic anachronist writers, whose practice was focused on domestic issues and more reactive-whether to the damaging effects of pragmatism, Supreme Court decisions, or black male lynching. English uses the work of playwright Suzan-Lori Park and her 2003 collection, 365 Plays, as an alternative method to healing temporal damage and creating political truths. Park's "positive anachronism" blends presentism's focus on simultaneity and creating community with anachronism's acceptance of the continued existence of the same racial injustices that have existed for centuries. By concluding her work with an analysis of Park, English fully demonstrates that not only the past, but the future of African American literature is concerned with the interweaving of race, time, and justice.

If there is any critique to be made of Each Hour Redeem it is in terms of its organization and analytical balance. For example, chapter 4, "'Seize the Time!': Strategic Presentism in the Black Arts Movement," (the title refers to Black Panther Party co-founder Bobby Seale's 1970 account of the party's founding with Huey P. Newton) begins with a discussion of the Dasein group of poets based at Howard University. It then moves chronologically to Black Nationalist and Black Arts Movement writers and intellectuals, and closes with a discussion of the Harlem Renaissance. Whereas other chapters progress chronologically, one is left questioning when reading about the Dasein poets why she skipped over the attention to jazz paid by Langston Hughes, James Weldon Johnson, and others (by this point her roadmap in the introduction is out of view of the rearview mirror). It is a bit disconcerting to expect this analysis, question its absence, and then find it in an unexpected location. In addition, English's analysis of the presentist writers is quite small in comparison to her readings of the novels by anachronist authors. She provides a brief overview of the views of Alain Locke, Zora Neal Hurston, Langston Hughes, and other Harlem Renaissance authors, but one almost wishes she would have engaged with their work more. Given the amount of research on the Harlem Renaissance, and that Each Hour Redeem's readers are likely to be familiar with these works, this is perhaps not a major problem. On the other hand, English devotes about the same attention to a small number of Walter Mosley's novels as she does the entire Black Arts Movement; this unbalance is palpable.

Like English, Bruce Barnhart is concerned with the relationship between the conceptualization and organization of time and racial marginalization and oppression, as well as the ways in which novels can ameliorate those effects. In 
Jazz in the Time of the Novel, Barnhart investigates the interactions between the aesthetic forms of the novel and jazz in the first three decades of the twentieth century. His analysis focuses on how the novel, as an aesthetic form, "refracts, redacts, incorporates, and suppresses jazz and its aesthetic and social logic" (1-2). Time links the novel with jazz, and each have their own way of treating time. Being the invention of white bourgeois society, the novel espouses the kind of universal and objective clock time of modernity that the African American authors English analyzed critiqued. Barnhart, following Johannes Fabian's theories of time, finds time to be a political force that creates racial oppression and enforces the stratified and unjust social hierarchy that capitalism relies upon. Jazz, on the other hand, according to Barnhart, "critiques existing modes of temporality." As such, the aesthetic form of jazz and its ability to unsteady the "mechanisms and machinations of objective clock time" can be used to counter the racial oppression brought by this objective clock time (7).

The stakes of Barnhart's study are significant. Looking at how novels pay attention to jazz, he argues, can "reveal a great deal about how they configure time and thus about their social and racial vision" (11). As a "genre of linear, progressive time" (20) the novel must identify an Other and define it as inferior in order to move forward towards its resolution. The novel's identification of an inferior alterity serves to oppress racial minorities; therefore, Barnhart argues, choosing to write a novel based on a different conception of time can combat this oppression. Adopting jazz's subversive conception of time is one method to demystify and call into question the dominant notion of time as an unchanging constant, thereby combating racial oppression. As English notes above, this critique of time has been an enduring feature of the African American literary tradition, and Barnhart works to show how this push and pull between competing notions of time and aesthetic forms plays out in the fiction and jazz of the early twentieth century.

Barnhart devotes a large majority of his time analyzing literary texts. He shows how in The Autobiography of an Ex-Colored Man, James Weldon Johnson critiques the logic of sublimation - or, the notion of a linear progression of cultural advancement that has the same racist effects as objective clock time - by demonstrating how sublimation's promises are false and impossible to attain. Whereas James Weldon Johnson critiqued logics that valued and underwrote objective clock time, F. Scott Fitzgerald supported "a conception of time and progress that jazz calls into question" (97). In The Great Gatsby, Fitzgerald devalues the nostalgic embrace of the past and advocates for what Barnhart calls a "snobbish repetition" that ensures that access to money and power should only be available to those with the right cultural values (i.e. people like Tom Buchanan rather than Gatsby). Fitzgerald's critique of sentimentality and what he saw as the decline of American culture during the Jazz Age, along with his literary modernism, displays his belief in the kind of naturalized time that jazz time works against. Barnhart also compares and contrasts the ways in which the works of Ernest Hemingway (The Sun Also Rises), Langston Hughes (Not 
Without Laughter), and Gertrude Stein (The Three Lives) embrace or reject the simultaneous expression of different rhythms and temporalities. Jazz in the Time of the Novel concludes with Barnhart's lengthy reading of Nella Larsen's novel Quicksand. He juxtaposes the biracial protagonist Helga Crane's negative reaction to "jungle music" and its negative associations with an uncivilized and primitive past against Duke Ellington's ability to call upon and repeat past traditions to construct his new and vital jungle music. Like Johnson employing jazz temporality to critique sublimation, Larsen's use of the "aesthetic imperatives of jazz" is part of a larger effort by African Americans to create new cultural forms, to define their culture, and to change the culture of those who oppress them (205).

Barnhart also shows how musicians use similar concepts of time to critique objective clock time and open up the future to new, more egalitarian possibilities. He uses his analysis of The Autobiography as a point of departure to argue that pianist and composer James P. Johnson is the novel's coauthor. He suggests that James P. Johnson's use of repetition and syncopated rhythms in his composition "Carolina Shout" provides a similar critique of sublimation to James Weldon Johnson's. Bessie Smith's 1925 recording of W.C. Handy's composition "St. Louis Blues," on which she is accompanied by Louis Armstrong and organist Fred Longshaw, demonstrates how musical gestures such as a wide vibrato, manipulations of pitch, and polyphonic textures - as well jazz musicians' simultaneous confrontation with the past, present, and future-undermines and neutralizes linear temporality and offers new potentials for the future. These jazz musicians, although Smith's and James P. Johnson's desgination as jazz musicians is arguable, are in stark contrast to those such as Paul Whiteman, who sought to subsume jazz into the logic of naturalized and objective clock time. Assuming Barnhart's use of black music as an analytic framework holds up (more on this later), he logically and somewhat convincingly argues his point. At the very least, he contrasts black music's conception and deployment of time to critique those authors who would naturalize time.

Ultimately, and not surprisingly, Barnhart concludes that jazz temporality's valuing of the past, its ability to repeat the past in ways that open up the future for new directions and social structures, and its embrace of the simultaneous existence of multiple temporalities, provides the best tools with which to deal with the realities of American culture and society. For Barnhart, jazz time allows us to understand that "the present can't be anything but a loosely heterogeneous whole" and that "the jazz impulse" provides a framework that has the potential to "lead to compelling and capacious aesthetic and social formations" (209). He claims that the texts - both literary and musical — that he reads that use jazz temporality "have contributed the most to a productive construction of time" (208). While Barnhart does not back up this claim with examples, or specify what he means by productive (one assumes it means that jazz temporality helps combat racial and social inequalities), he makes it clear, as does English, that aesthetic forms can be used to alter social relations.

While there are moments of brilliance in Jazz in the Time of the Novelsuch as Barnhart's interweaving of Hegel, Adorno's reading of Kant, and Robyn 
Wiegman's theorization of lynching to highlight the linkages of the construction of time, notions of progress, and racial ideology with the lynching in The Autobiography - there are several instances where Barnhart's analysis is, at best frustrating, or at worst, highly problematic. These tend to do with the ways in which he defines music and the work that it does, which is symptomatic of some literary criticism that grounds itself in analyses of music, especially jazz. It is not surprising then, that his most illuminating, effective, and convincing work is when he discusses jazz as a musical practice the least, as is the case with his chapter on Fitzgerald.

Barnhart's definition of jazz and the way he uses it as an analytic framework is unclear and generalized, which is troublesome, given that it is the foundation of his analysis. At times it seems as if Barnhart is treating jazz as a genre that is comprised of musical gestures and approaches. He notes jazz's emphasis on rhythm, repetition, improvisation, and swing feel. He also asserts that "jazz bases itself on repetitive cycles that allow any piece to be compressed or telescoped as the performance situation requires: three minutes for a recording session, one minute to signal a band's impending break, fifteen minutes for a really jumping dance hall, or all night for a Kansas City jam session. . . J Jazz's beginnings and endings are, in a certain sense, arbitrary" (17). These statements are problematic in several ways. While the former may be true in some in some instances, it may not be in others. And the beginning and endings of jazz are anything but arbitrary, as musicians decide when and where to begin and end their performances, whether freely improvised or heavily composed. In his characterization of jazz as having arbitrary beginnings and endings, Barnhart treats it as a genre that is plucked from the simplest distillation of black music as endlessly repetitive and cyclical. Barnhart writes of jazz as a genre with just enough specificity (repetition, swing, improvisation) to indicate that he is talking about something, but does so in a way that is just general and vague enough so that jazz can mean anything. What kind of jazz is he speaking about? Played by whom? In what style? In what context? Presumably he is referring to jazz in the first third of the twentieth century, but it is not clear. In writing about jazz as a genre, but by relying upon general characteristics to define it, Barnhart makes jazz into a music that can be anything and nothing.

On the other hand, Barnhart may not be treating jazz as a genre at all. In using Houston Baker's definition of form as "a symbolizing fluidity, ... . a family of concepts or a momentary and changing same array of images, figures and assumptions" and as a "mode of action" $(10,90)$, Barnhart conceptualizes and treats jazz as consisting of an aesthetic approach as opposed to a genre. In this way, jazz would be akin to Amiri Baraka's "the changing same." However, by referring to "jazz music" and "jazz musicians," Barnhart implies he is referring to it as a genre, which is further problematic given that he conflates jazz with ragtime and blues throughout. Although each is related to jazz, they are distinct genres. Throughout the text the reader is unsure as to how Barnhart defines jazz. Is it a genre with musical characteristics that separate it from other genres? If so, his generalizations do not do it justice, nor help the reader. Is it a form, in 
Baker's sense? Is it something that consists of a "family of concepts"? Is it a value system, an outlook, a mode of expression, or a genre? It is just not clear. This is unfortunate, given that his entire argument rests upon his definition of jazz. ${ }^{7}$

Not only are Barnhart's definitions and conceptions of jazz at times too general and unclear, some of his readings of musical texts are questionable. His analysis of James P. Johnson's "Carolina Shout" is one example. He notes the piece's rhythmic power and repetitive form as comprising the primary elements of its critique of sublimation and objective clock time. The piece has several sections which repeat, and although Barnhart uses this repetition to further support his argument that jazz temporality challenges linear time, the use of repeating sections in ragtime come from the Western musical tradition, and can be seen in the repeating strains of marches, a form highly influential to ragtime. Repeating sections grouped in eight or sixteen measures goes back much further than military marches, as binary and ternary form are centuries old and the building blocks of Western art music form. Barnhart argues that Johnson's use of a hemiola-a compositional device in which a grouping of three is played against a grouping of two - represents an "occupation with the absolute disquietude of the moment and the aliquant inseparability of past, present, and future it engenders" (91). While this may be so, the hemiola is not a device unique to ragtime, jazz, or other black music. That European composers have long utilized repeating sections and hemiolas in familiar forms, such as symphonies, concerti, and masses, suggests that Johnson's use of them is not a unique strategy with which to combat a specific notion of time. If anything, it shows some of the influence that Western music had on black music. While Barnhart may argue that it is the context and ways in which these devices are used that matters - and he would be correct in that assertion - the fact that Johnson uses them, and that Barnhart reads them in a particular way, is not proof enough of their critique of linear time.

Just as Barnhart's inconsistent, unclear, and generalized definition of jazz destabilizes his argument, so too does his characterization of the symphony in his chapter on The Autobiography. The nature of the symphony is key here, as Barnhart uses a particular understanding of the symphony as the framework upon which he builds his reading of the way Johnson uses the symphony to critique sublimation. As a form that transports the listener into a "sublime transcendent space" and in "wield[ing] force in an effort to make time appear as a natural rather than a social force" the symphony represents the sublimation process in action $(66,68)$. That the narrator is unable to compose his symphony is one of the ways that Johnson shows that sublimation is an impossible goal, which reveals time to be the social force that it is. Barnhart relies upon Adorno's view of the symphony as a form that delivers the listener "from the threat of repetition and consecrating a nonreflexive unidirectional experience of time" and provides a "massed sound" that transports the listener "into a sublime transcendent space overwhelming enough to separate those who enter it from their private experience" $(65,66)$. While Adorno's views of the symphony dovetail perfectly with Barnhart's argument that the symphony's use of linear time - like that of the novel—ossifies 
racial oppression and represents the narrator's progression to whiteness and sublimation in general, it is only but one interpretation of a centuries old form that has evolved greatly. Mozart and Haydn were commissioned to write their symphonies as little more than background music — a far cry from delivering the listener into a "sublime transcendent space." The symphony and its effects on the listener can hardly be pinned down to the narrow conception Barnhart adopts. Which symphony? When? Written by whom? For what purpose? Reflecting what set of cultural values? Barnhart's reading of Johnson's critique of sublimation only holds up insofar as it relies on a one-sided and historically-absent definition of the symphony; to acknowledge the history and various specificities and dynamism of the symphony would be to acknowledge that his argument cannot exist with anything other than a generalized definition of the form.

In some ways, Jazz in the Time of the Novel represents the inherent danger and difficulty of writing literary criticism that relies so heavily on a framework built upon musical practice. Barnhart's readings of musical texts, while grounded in critical theory, rarely draw on a wide range of musical scholars. This is not to advocate for a more traditional musicological approach; rather, citing musicologists in addition to social theorist Max Weber would serve to boost his claims about the links between rationality, tuning, harmony, and the Western art music tradition. The problems in his readings are intensified based on his highly abstract and subjective interpretations of novels and music. ${ }^{8}$ In Each Hour Redeem, English very clearly links her readings with the views of those she studies. This is largely not the case in Jazz in the Time of the Novel, where Barnhart's readings often come across as little more than subjective speculation unmoored from empirical evidence. Did James Weldon Johnson write The Autobiography to critique the objective clock time? Was he consciously using jazz's approach to rhythm and time to wage such a critique, or for any other purpose? Was Louis Armstrong's use of a wide vibrato an attempt to critique the logic behind Western tuning and time? And more generally, while using the concepts of Hegel, Adorno, Lukács, and other theorists to draw out the ways in which jazz and the novel deal with time requires complicated writing, there are many instances in which Barnhart's prose is unnecessarily dense, overwrought, which at times serves to occlude his argument. Ultimately, although Jazz in the Time of the Novel provides at times novel, logically argued, and insightful readings into the ways in which major texts of early-twentieth-century literature and music approached the use of time, Barnhart's generalized, abstract, and unclear definitions of music, along with a general lack of convincing evidence, make for a frustrating read.

Taken together, Each Hour Redeem and Jazz in the Time of the Novel provide two very different ways of approaching the problem of time in American culture and the ways in which it structures social hierarchies and works to marginalize certain groups. English and Barnhart provide their readers with both macro and micro looks at how African American authors - as well as some musicians - have approached the knotty interaction of time, race, and justice. Much has been made of the so-called "post-racial" era that supposedly began with the 2008 election 
of President Obama. The use of the "post" prefix is indicative of the ways in which Americans construct their nation's narrative: that the problems of the past are solved and remain in the past. This is echoed on the lips of every politician: "America's best days are ahead of us." That the centuries old problems African American writers have consistently critiqued still exist, as expressed so directly and eloquently by Killer Mike, and seen in the headlines of stories about Michael Brown, Trayvon Martin, and Eric Garner, demonstrates the need to continue to be aware of the ways in which race, justice, and time still exert force on marginalized communities. English's and Barnhart's books are a reminder that if we read - and listen — carefully, we might just begin to make changes to secure a better and more egalitarian future.

\section{Notes}

1. Killer Mike, R.A.P. Music, Williams Street 384-460-018-2, 2012, compact disc.

2. Among other albums, see: N.W.A., Straight Outta Compton, Ruthless Records CDL 57102, 1988, compact disc; Public Enemy, It Takes A Nation of Millions to Hold Us Back, Def Jam 314527 358-2, 1988, compact disc; Howard Wiley \& The Angola Project, 12 Gates to the City, self release, 2010, compact disc; Gil Scott-Heron, Pieces of a Man, Flying Dutchman FD 10143, 1971, LP; Max Roach, We Insist! Freedom Now Suite, Candid CJM 8002, 1960, LP; Charles Mingus, "Original Faubus Fables," Charles Mingus Presents Charles Mingus, Candid CJM 8005, 1960, LP.

3. In this way, the English and Barnhart provide concrete examples and analyses of the relationship between aesthetics and politics that critics such as Jacques Rancière theorize. See Jacques Rancière, Dissensus: On Politics and Aesthetics, ed., trans. Steve Corcoran (London: Continuum, 2010).

4. See Henry Louis Gates, The Signifying Monkey: A Theory of Afro-American Literary Criticism (New York: Oxford University Press, 1988), 127-69.

5. For more on the relationship between jazz and Black Arts Movement writing, see: Scott Saul, Freedom Is, Freedom Ain't: Jazz and the Making of the Sixties (Cambridge, MA.: Harvard University Press, 2003), 244-70. Eric Porter, What is this Thing Called Jazz?: African American Musicians as Artists, Critics, and Activists (Berkeley, CA: University of California Press, 2002), 191-239. For more on the relationship between black music and black poetry in general, see Tony Bolden, Afro-Blue: Improvisations in African American Poetry and Culture (Urbana: University of Illinois Press, 2004). Meta DuEwa Jones, The Muse is Music: Jazz Poetry from the Harlem Renaissance to Spoken Word (Urbana, IL: University of Illinois Press, 2011). Aldon Lynn Nielsen, Integral Music: Languages of African American Innovation (Tuscaloosa, AL: University of Alabama Press, 2004). Aldon Lynn Nielsen, Black Chant: Languages of African-American Postmodernism (Cambridge: Cambridge University Press, 1997).

6. See Amiri Baraka, Black Music (New York: Akashic, 2010), 205.

7. Barnhart's difficulty in stating a clear definition of jazz is a common problem. Fritz Gysin points out that although "the crossing of boundaries" between literature and jazz "seems to have become a pastime of writers and critics alike; it is, however, not unproblematic. Above all, it raises questions about the positioning of the term within the theoretical or hermeneutical hierarchy as well as about the applicability of the phenomenon to the fictional/critical/theoretical discourse." Fritz Gysin, "From "Liberating Voices" to "Metathetic Ventriloquism": Boundaries in Recent African-American Jazz Fiction," Callaloo 25.1 (2002): 275. Italics in original.

One question that arises out of Gysin's observation, and which permeates Barnhart's work, is: Which jazz? James Harding points out that a common problem to criticism that uses Theodore Adorno's writing on jazz is that the music "is handled as a homogenous collective entity, which thus obscures the internal dynamics of jazz and attributes it to a privileged ahistorical status." Harding's critique of literature that defines jazz in such monolithic terms applies completely to the ways in which Barnhart defines and treats jazz. James M. Harding, "Adorno, Ellison, and the Critique of Jazz," Cultural Critique 31 (1995): 130.

8. The lack of specification in Barnhart's definition of jazz, along with the subjective nature of his readings are not isolated instances in jazz-focused literary criticism. As Gysin points out, "not only the is the choice among useable Jazz elements extremely wide, but the terminology is also conveniently ague, so that almost anything under the sun can be characterized as a solo, and arrangement, an improvisation, a riff, a bridge, etc." Gysin, "From 'Liberating Voices' to 'Metathetic Ventriloquis': Boundaries in Recent African-American Jazz Fiction,” 275. 